
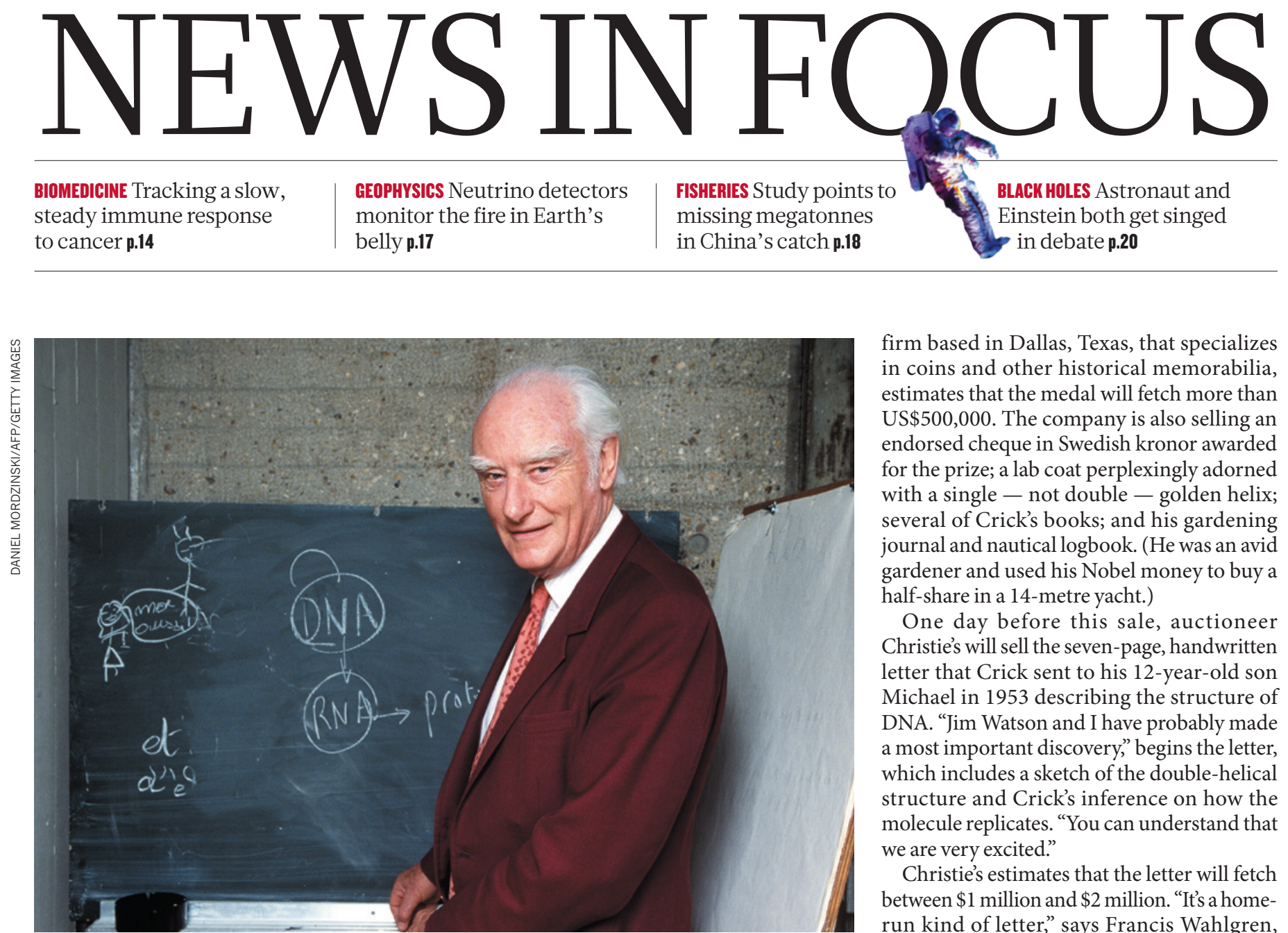

Francis Crick's co-discovery of the structure of DNA laid the foundations of molecular biology.

\title{
SCIENCE HISTORY
}

\section{Crick's medal goes under the hammer}

\section{Pending auction raises eyebrows but few objections.}

\section{BY EWEN CALLAWAY}

$\mathrm{B}$ efore he and James Watson made the defining discovery of the twentieth century, Francis Crick was an impoverished $\mathrm{PhD}$ student. The future Nobel laureate twice left his typewriter with a pawnbroker in exchange for a loan, and his family helped Crick and his wife Odile to make ends meet.

Now he is - posthumously - repaying that generosity. Crick's family stands to gain more than a million dollars after his Nobel medal and other memorabilia go to the auction block next week in New York. The sale has been met with speculation and curiosity, but also with some shrugs. Historians are less interested in the glittery prize that Crick won five decades ago than in some faded bits of paper that are also up for bidding: a letter from Crick to his son describing the landmark 1953 discovery.

Public attention, however, has focused on Crick's Nobel medal since its 11 April sale was announced. The 23-carat-gold medallion was awarded for the 1962 Nobel Prize in Physiology or Medicine, which Crick shared with Watson and Maurice Wilkins for their work on determining the molecular structure of DNA and its role in heredity. Crick put the medal in a family trust in 1990.

Heritage Auctions, a firm based in Dallas, Texas, that specializes in coins and other historical memorabilia, estimates that the medal will fetch more than US\$500,000. The company is also selling an endorsed cheque in Swedish kronor awarded for the prize; a lab coat perplexingly adorned with a single - not double - golden helix; several of Crick's books; and his gardening journal and nautical logbook. (He was an avid gardener and used his Nobel money to buy a half-share in a 14-metre yacht.)

One day before this sale, auctioneer Christie's will sell the seven-page, handwritten letter that Crick sent to his 12-year-old son Michael in 1953 describing the structure of DNA. "Jim Watson and I have probably made a most important discovery," begins the letter, which includes a sketch of the double-helical structure and Crick's inference on how the molecule replicates. "You can understand that we are very excited.”

Christie's estimates that the letter will fetch between $\$ 1$ million and \$2 million. "It's a homerun kind of letter," says Francis Wahlgren, international head of rare books and manuscripts at the auction house. In assessing the letter's worth, he cites its scientific importance - the letter is one of the first written descriptions of DNA's structure, preceding its scientific publication by weeks - as well as its personal sentiment. Half of the letter's sale money will be donated to the Salk Institute for Biological Studies in La Jolla, California, where Crick ended his career. And at least $20 \%$ of the money from the sale of the medal and the other items will benefit the Francis Crick Institute, a biomedical centre under construction in Central London.

Kindra Crick, a granddaughter of the laureate who is an artist in Portland, Oregon, says that the medal has been in storage for decades, and that her family hopes a buyer will make it available for public display. "It's challenging to know what to do with something like this," she says. "We pretty much figured that the types of people who would want to bid on this unique part of science history would have the resources to make it available for public display and not keep it locked up."

"That is not at all guaranteed," says Soraya de Chadarevian, a science historian at the University of California, Los Angeles. Still, she sees the medal as more of a collector's item than an important artefact from the dawn of molecular biology. The letter to Crick's son would 
- be of much more interest to historians, she says, because it contains an early sketch of DNA. That, she adds, "would be much better placed in an archive".

In the early 2000s, Crick nearly sold his papers to a private buyer. Watson urged him to reconsider the sale, and in 2001, the Wellcome Trust, a London-based biomedical charity, purchased the papers for $£ 1.6$ million (US\$2.4 million). The Wellcome Library recently launched a website containing digitized versions of the collection.

Simon Chaplin, director of the Wellcome Library, says that the Crick memorabilia now at auction are a "low priority" for Wellcome. "I think it would be nice if the medal could be available to the public, but I feel it's more important to present the substance of somebody's research than to focus on individual items that may be intrinsically valuable," he says. He suggests that the medal and other items would be better suited to London's Science Museum: its collection includes a reconstruction of Watson and Crick's first model of the DNA double helix, complete with some pieces from the original model, which was destroyed.

Robert Bud, the museum's principal curator of medicine, says "it's our business whether

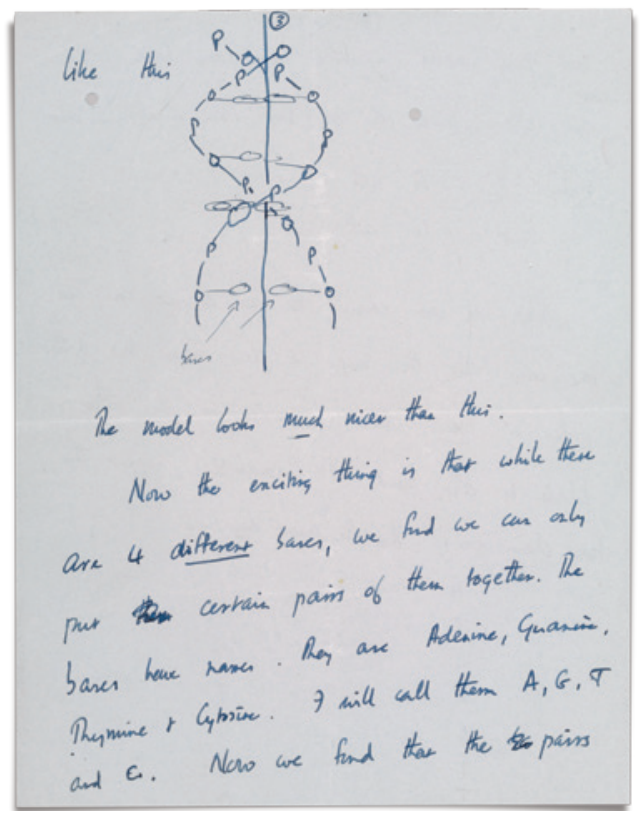

"A most important discovery," wrote Crick to his son.

we're going to bid for it", but that "if somebody were to give it to the Science Museum I would doubt we would reject it". Museums, adds Bud, can make scientific memorabilia more worthwhile by presenting objects within a larger story. "It makes the past real, and enables you to believe that the future with which you're working has a real ancestry," he says.

It is uncommon - although not unheard of - for scientific collectables to wind up at auction, adds Bud. In 1997, his museum bought a preserved penicillin mould, prepared by Alexander Fleming, for around $\$ 25,000$ from Christie's. And in November 2012, a Danish auction house garnered 280,000 Danish kroner (US\$48,000) for the Nobel medal that Aage Niels Bohr won in 1975 for his theoretical work on the structure of the atomic nucleus. His father Niels Bohr, a pioneer of the field of quantum physics, and August Krogh, the 1920 medicine laureate, auctioned their medals in 1940 to raise money for a fund to aid the Finnish people during the Second World War. An anonymous buyer has since given the medals to the Danish Historical Museum in Fredriksborg.

Neuroscientist Charles Stevens, a former colleague of Crick's at the Salk Institute, isn't bothered by the family's decision to auction the medal. "The things that I would treasure from him are things he actually did," he says. Nor does he think that Crick would mind. "Francis didn't make the medal - he just won it. I'm sure he was glad he got it, but I doubt he would be very sentimental." -

\section{Sizing up a slow assault on cancer}

\section{Rise of immunotherapies spurs search for markers of response.}

\section{BY HEIDI LEDFORD}

$\mathrm{J}$ edd Wolchok braced himself as he walked into the examination room to deliver bad news to his patient. Scans showed that the man's advanced melanoma had spread, and new tumours had sprouted, even though he had received an experimental therapy called ipilimumab (Yervoy) to rally his immune system against the disease. "In my mind I was rehearsing the standard speech," says Wolchok, an oncologist at the Memorial Sloan-Kettering Cancer Center in New York. "I'm sorry Mr Soand-so, but the treatment doesn't seem to be working." Instead, the patient stopped Wolchok at the door. "Now before you show me your pictures, let me tell you: I feel better," he said.

Wolchok took a gamble, and continued the therapy. More than six years later, his patient is thriving, and the drug, made by Bristol-Myers
Squibb of New York, has been approved by the US Food and Drug Administration. In that time, other experimental immunotherapies have shown promise, and clinicians have become increasingly familiar with delayed responses such as the one Wolchok's patient experienced - which reflect a gradual attack by the immune system, in contrast to the rapid onslaught of toxic chemotherapies. They still have no tools to quickly discern which patients are benefiting from treatment, but that may be about to change.

At the annual meeting of the American Association for Cancer Research in Washington DC this week, Wolchok and other researchers will report on their search for immunotherapy markers - ways to predict a patient's response to an immunotherapy or to show whether a given treatment is working. The work is hampered by the complexity of the immune system,

but early results are converging on one point: that patients' own immune responses to cancer are crucial in determining outcomes.

"When you sum it all up in many different cancers, early and late stage, it looks like patients who have a 'smouldering' initial immune response to cancer are more likely to benefit from immune therapies," says Thomas Gajewski, a cancer researcher at the University of Chicago in Illinois. Early work suggests that such patients may fare better, irrespective of the therapy used to treat them, he says. The evidence is fuelling a push to add an immune component to standard tumour pathology evaluations (see 'T cells can brighten

"It looks like patients who have a 'smouldering' initial response to cancer are more likely to benefit." prognosis').

Reliably gauging the initial response, however, is a challenge, cautions Mario Sznol, an oncologist at Yale University in New Haven, Connecticut. The immune response is a moving target, influenced not only by a patient's genetic make-up and environment, but also by proteins secreted by the tumour that can suppress immune cells. Immune markers present in the blood may not reflect what is happening in the tumour, and variation within a tumour means that biopsies may not paint a full picture either, if the needle misses 